\title{
The Demonization and Recovery of Religion: Villains and the Transformation of Narrative
}

\author{
Verna Ehret
}

\section{Introduction}

Reading religious history, ethics, biblical scholarship, along with a host of other disciplines, what one discovers is a consensus that there is no value free, objective, non-interpretive experience of the world. Hermeneutics in particular raises consciousness of the complexity of human engagement with the world. ${ }^{1}$ While hermeneutics has been focused on the understanding of texts, authors, and readers, the field of hermeneutics need not be limited in this way. Forrest Clingerman ("Interpreting Heaven and Earth"), for example, has taken hermeneutics into nature where interpretation of place and oneself in relation to place is a broadening of the hermeneutical enterprise. Hermeneutics as an art and science of interpretation opens up understanding and meaningfulness as one takes in and makes meaning out of our reality as we see it.

The "as we see it" is important. Interpretation does not happen by simply taking in data. Interpretation comes within the context of the values and perspectives already present to a person, as Gadamer (Truth and Method) pointed out, each person has a hermeneutical horizon. Moreover, as seen in the work of thinkers such as John D. Caputo (More Radical Hermeneutics), each person's horizon is distinct, which creates a gap between one's own horizon and that of the other. 
Living in the world requires sorting through the information constantly being received, and the only way to do that is through the lens already given to each person. This unfolding of interpretation is the creation of narrative.

This narrative is one's worldview. One does not simply interpret individual bits of information but unfolds them in relation to each other, into the story that shapes one's identity. Narrative, then, is how one experiences the world. Each of us has a narrative identity, to borrow a phrase from Ricoeur (Oneself as Another). Each person understands him or herself through the way that person unfolds the interpretation of history, the present, and the possibilities for the future in constant interaction with the other. As Philip Davies describes it:

Stories are never innocent of point of view, plot, ideology, or cultural value. We tell our stories of the past in a historical context, looking at the past from a particular point: the present. We cannot be objective, neutral observers. We ourselves are in history, in the sense both of events happening and of the stories (news, gossip, history books) that interpret these eventsnot to mention our own memories. (Memories 11)

Our narrative identity is not simply the past of ourselves, it is culturally constructed — what Davies calls cultural memory and others (including myself) call sacred history. Within the life of a person who considers him or herself religious, there is a particular quality to the narrative, and that is the relationship with the holy or sacred as the driving force of the narrative. In such narratives, everything is at stake. The unfolding of one's story in relation to the holy, one's narrative identity, is in relation to one's community, cultural period, and place in time. And these narratives point to the future of how the narrative will continue to unfold. As Ricoeur pointed out, the process of hermeneutics is a dialogue, a continual back and forth with that which one is interpreting ("What Is A Text"). And in the case of personal and communal identity, one is always adding to the story of life itself and its telos by every interaction with the world. Others, then, are characters in our own stories.

The underlying assumption of this essay is that there is no non-narrative engagement with the world. One is always in the process of interpreting the world in light of the pre-existing narrative and adding to that narrative through new experiences. But there is a problem with the assumption. In the postmodern turn of the mid and late 20th century, narrative was challenged. In terms or religious narrative, Mark C. Taylor provided a critique in Erring: A Post-modern $A$ /Theology that can support the claim that certain ways of unfolding narrative 
can lead to inauthentic engagement with the world. The attempt to fold all of understanding and Truth (with the capital T) into a single over-arching point of view was unveiled as deeply flawed, requiring disengagement with the everchanging human experience of the world and the limitations of human understanding. There is no such singular point of view, although history itself is riddled with attempts to create one. Such narratives are referred to as meta-narratives, narratives of the whole that seek to eliminate dissenting voices in order to create a uniform position on what is True about humanity, history, and the future.

Religion narratives can be dangerous. Through the narrative structures of religion people have justified a multitude of acts of violence, and looking at these there would seem to be many religious villains. For the victims of the violence, the person(s) and the religion he or she may claim to represent are villainous. At the same time, the ability to do extreme violence to another requires seeing the other as a villain who is a threat to oneself or one's community. This threat may be ideological, moral, social, political, or even physical. It may be real or perceived. As a result, that person is perceived as a threat. In the domain of religious violence it can seem easy to identify religious villains. Take, for example, the attacks in Norway by Anders Breivik in 2011. These show villainy in the name of ideology when he killed more than 70 people to "protect" Norway from supporters of Muslim immigration and multiculturalism. ${ }^{2}$ Throughout his trial he has remained unrepentant regarding these acts of violence. As one reads about the trial or watches video clips of him speaking, he seems to embody villainy.

This event raises a series of questions regarding the ability to identify and respond to religious villains. What is it that makes one person see Breivik as a villain and others see him as a hero? One way to understand it is through the difference between those whose story promotes diversity and multiculturalism and those whose story is threatened by it. If so, is it possible to choose a position that is more correct or must one simply accept that there is no better or worse position here? In other words, should relativism drive one's analysis or can a standard of evaluation be applied? If relativism is the "better" option, and no standard of evaluation is possible, then there is no discussion to be had because there are no religious villains. However, it is possible to employ a standard of evaluation without being inflexible in that standard. Standards can still take context into account. Identifying a religious villain, then, is more complicated than simply identifying someone with whom one aggressively disagrees or finds abhorrent. Religious villainy is grounded in narrative as that which drives action. The foundation of one's narrative perspective regarding the other will reveal a way to determine villainy in religion.

To call another living human being a villain is to pass an extreme judgment on 
another person's character and the freedom of his or her agency. A villain is not simply a person who does something bad, even if it is shockingly bad. To call another person a villain is to say first that the person has a choice on whether or not to act in vicious ways and chooses evil, and second that given the opportunity to change, the person would choose not to do so. One then has to consider what makes an act vicious or evil. Breivik killed 77 people, many of whom were in their mid-teens. He blew up a building and then went to a summer camp and started shooting. His trial has had a great deal of testimony from survivors of the attacks, many of whom have suffered irreparable harm. He chose to do these things and would do them again. What makes them vicious and evil is that they are based in a narrative that limits human flourishing to a specific segment of humanity while imposing that narrative on the whole through one's actions. Breivik destroyed the lives and flourishing of some in order, as he saw it, to promote the flourishing of others.

The acts show a disregard for any value, dignity, or integrity of the lives of those who disagree with him. Their lives are unworthy of the value, dignity, and integrity he would give to those who support him. As a result, he may be a prime example of a religious villain. This essay asks two primary questions: are there religious villains, and if so, can anything be done to mitigate the damage they do? Using the standard of threats to the integrity of life, as identified in theological humanism, as a foundation to a narrative that make room for the alterity of the other makes it possible to identify both villainous acts and villains of religion. The path to transforming religion and resisting villainous religion comes in an understanding of the evolution of religious narratives and the proposal of an alternative approach to religious narratives in order to engage people differently than simply perpetuating the cycle of villainizing.

The goal of this essay, then, is to understand the narrative foundations of religious villains. To be a villain is to be the villain of a story. In order to understand the religious villain requires understanding how narrative unfolds in religion. There are three types of religious villains: 1 ) those who have been cast as villains by someone else's narrative, 2) those whose narrative identity supports the destruction of others, and 3) those who are villains precisely because they villainize the other through a destructive meta-narrative. In each case, however, the villainy itself is the destruction of the integrity of life, made reasonable to the villain through the narrative in which he or she lives. But the interpretation of the integrity of life and threats to it also is a hermeneutical enterprise. I do not argue, then, that the simple fact of a multiplicity of narratives means all narratives are equal. By employing the hermeneutical lens of the integrity of life I am arguing that religious narratives and the understanding of villains within them can be evaluat- 
ed by this standard. The standard is fluid because it recognizes not only the value and integrity but also the alterity of life.

\section{Religion and Narrative}

Religion has been described by Protestant theologian Paul Tillich as being the centered act of the whole personality (Tillich Dynamics 4-9). Tillich's claim is that religion is the union of faith, the state of being grasped by an ultimate concern, and belief, the concrete content of faith in ritual, symbols, and narrative. Religion is awareness of how the parts of oneself fit together in a unified whole oriented toward the holy (Tillich What Is Religion? 72-75). Religion provides a path for finding meaning and value in life. (Tillich Courage 160-163). His understanding of the role of religion is built from the idea seen in Plato's Republic (Book IX), Augustine's Confessions (Book II), and others that living well as a human being is to have a well-ordered soul, all of the parts of who one is coming together in a harmonious balance. Religion, broadly conceived as ultimate concern (Tillich Systematic 11-12) rather than narrowly as "belief in God" or other kinds of beliefs, provides a path for one to realize one's full human potential by providing a sacred center around which a life can be built, as described famously by Eliade in The Sacred and the Profane (22). This center is expressed in religious narratives, and carries ultimate weight in a person's life. It is that around which life itself is built for the religious person.

It is through narrative that we understand ourselves as beings in relation to a larger world. Paul Ricoeur describes narrative in Figuring the Sacred as having four resources: 1) The art of emplotment - the activity of creating a narrative by ordering events. In the creation of religious narrative one can describe this as the unfolding of sacred history, the story of a community in relation to the holy. 2) The epistemological status of the intelligibility created by emplotment- that we can know the world because we can make sense of it. For the religious community it is the sense that we are in a story with guidance, often through the revelation of sacred texts and the tradition that interprets them. We "write" ourselves into the story through the idea that there is a plan for humanity laid out by the holy. 3) The role of tradition, which for Ricoeur is a dialectic of innovation and sedimentation, or the recognition of and engagement with one's context. When dealing with religious villains the context is two-fold - the insider sees a persecution of righteousness while the outsider sees the villainous distortion of righteousness into evil. 4) The meaning of narrative. The meaning of religious narrative is sacred history, the unfolding of a community's potential in relation to the holy 
(Ricoeur "Narrative Theology" 239-240). Through this unfolding of narrative the individual and community become themselves.

Ricoeur deals specifically with the intersection of text and reader, but his ideas need not be limited to that domain. Narrative is the unfolding of life, and religious narratives are narratives that see life unfolding around a particular center, the holy. The process of reading is the intersection of telling and living within a narrative, to which specific texts may contribute (Ricoeur "Text" 118). Through the way we envision and tell our own story we organize the information that constantly bombards us, giving a sense of identity and belonging in a world that has meaning and purpose. The role of such narratives is ontological. They place one before oneself and give one a sense of who one is, allowing one to interpret oneself in the process of narrating one's life. Religious narratives are living narratives because they are always unfolding through the dual movement of narration and interpretation. It is through this dual movement that religious narratives, when they work well, help the individual grow as a person through an ever greater understanding of one's center and relationship to the world.

Each religious narrative might describe a complete human life in different ways, but understanding religious acts from the standpoint of common humanity can provide a productive way to evaluate narratives lived and actions undertaken in the name of particular religious narratives. From the standpoint of basic human flourishing, there is such a thing as a religious villain. A religious villain is one who chooses, based on a particular religious narrative, to inflict radical suffering — destroying the integrity of life-and is remorseless in these acts. One who would do it all over again given the chance is a villain. But such figures are rare. Religious villainy can exist in less overt forms in the way narratives themselves are constructed, not only in the acts that arise from those narratives but also in the vary process of villainizing someone else. Narratives that villainize are also destructive of the integrity of life. Villainy in religion may be identifiable and in a sense irredeemable. One who holds to a narrative as an unchanging Truth perhaps cannot be swayed from it. However it may be possible to minimize the effects of such villains by transforming how narratives are understood. Narrative becomes a key to understanding religious villains and to curtailing their influence.

In understanding these narratives, then, they can be divided into three primary categories: meta-narratives, contextual narratives, and trans-contextual narratives. Meta-narrative is an attempt at unifying the whole of life experience into a single understanding and ideology. These narratives can become the tools of religious villains to both promote villainous actions and perpetuate destructive narratives that are themselves both support and tools for perpetuating religious villainy. Meta-narratives can become villainous on two levels. The first level is the narra- 
tive created by villains, those who directly destroy the integrity of life. The second level is narratives of villainy. Narratives are villainous here in two ways. On the one hand there are narratives that villainize the other and therefore justify the destruction of the human flourishing of the other. On the other hand, these same narratives are villainous - used as justification for both the destructive acts and unrepentant nature of religious villains.

The second form of narrative is the contextual narrative. The contextual narrative as a categorization of religious narrative is a postmodern development, a recognition that there is not one single narrative that explains all of life and is without point of view. ${ }^{3}$ Rather, narratives arise out of human experience and therefore are context dependent. All narratives in some sense are contextual narratives. The villainizing of any narrative is the realization of the destructive potential of how narratives are constructed and unfold. When narratives are given meta status they cannot recognize their own limitations in understanding the world. Recognition of the limitations of the human perspective as expressed through narrative is the first step to transforming narrative and combating religious villains.

The second step to the recovery of narrative and the capacity to move beyond the destructive influence of religious villains is to see the common ground between narratives. New narratives can be constructed that seek more broadly to promote the integrity of life and human flourishing by learning respect for the differences and the relationships that can be built within the interplay of similarities and differences. These narratives are called trans-contextual narratives. Trans-contextual narratives recognize the limitations of human perspectives and yet seek to build connections across narratives. The trans-contextual narrative is the meeting point and mutual respect of contextual narratives.

These three categories of narratives both identify forms of religious narratives and provide a way to understand how religious narratives can result in religious villains. Religious narratives of historical communities present the sacred history of the community, how they understand themselves as a community at once in relation to the divine and in a context. Unlike factual history, sacred history reads factual history through the lens of a community in relationship to God (Aslan No god But God xxvi). It is not a simple recounting of the past, but rather the ongoing self-understanding of a community projected into the future. Sacred history has, I argue, four components: 1) imagination, 2) interpretation, 3) context, and 4) application. In other words, the unfolding of sacred history is read through an image of the whole, that history itself is meaningful, giving value and purpose to life. In this image of the world one creatively interprets the events of history and applies them to one's present and future. 
But this process of interpretation is heavily dependent on one's context. What one brings to the story affects one's interpretation and therefore the story's unfolding. While the narrative itself gives meaning, belonging, and purpose to individuals and communities, the unfolding narrative itself is also shaped by the sense of meaning, belonging, and purpose already held by the interpreter. It is a dialectical and potentially volatile interchange of both narrative and identity development.

Given this understanding of narrative, it is possible to evaluate the quality of a religious narrative based on how well the story is told in a context of a multiplicity of differing and overlapping religious narratives. Well-functioning religious narratives, because they place us before our potential as human beings and give guidance on how to realize that potential in relation to others, reflect a concern with the integrity of life. This notion is unfolded through the discussion of theological humanism developed by David Klemm and William Schweiker in their book Religion and the Human Future: An Essay on Theological Humanism. The "integrity of life" as a standard used by Klemm and Schweiker has three important components based upon Todorov's, Imperfect Garden: The Legacy of Humanism. The integrity of life affirms 1) the autonomy of the "I," 2) the finality of the "you," and 3) the universality of the "they" (9). To affirm the "integrity of life" carries an obligation for care and concern in all these areas. The integrity of life, then, has both the sense of the value of all life and the interconnection of it.

Within theological humanism, life is evaluated in terms of a set of interconnected and over-lapping goods. First, basic goods preserve life itself. Second, social goods build life in community, and third, reflective goods provide the tools for making judgments about life. Together, the protection of these goods in a series of "oughts" or obligations is achieved through the "integrity of life." The integrity of life, then, means, "the integration of distinct levels of goods into some livable form, always threatened and always vulnerable, but without which personal or social life is impossible" (Klemm and Schweiker 4:5). Second, integrity of life means, "a life dedicated to respecting and enhancing the proper integration of those goods and thereby a commitment to the well-being of other forms of life. In this second sense moral integrity is the wholeness and steadfastness that is the proper aim of human existence with all of its vulnerability and fallibility" (Klemm and Schweiker 4:5).

Based on these core notions of the integrity of life, the common good entails all three types of goods for human beings simply because they are human. In evaluating religious villains as well as villainous and villainizing narratives, the integrity of life is a useful standard of judgment. It speaks to the heart of religion as the growth of human beings in the fullness of our humanity, and that the reali- 
zation of our full human potential is interconnected to the flourishing of others. This core idea of the integrity of life can be seen as the center of religious narratives when they work well. However, religious narratives do not always work well.

\section{Meta-Narrative and Religious Villains}

Meta-narrative is the term that has been given to sacred histories that purport to bring the whole of reality and history itself into clear focus, incorporating some and rejecting other narratives. These narratives may make life clear, though not simple. In an age of globalization there are a multitude of narratives immediately available. This plurality presents great challenges to one's world view as well as social, political, and economic life. The resulting threat to one's identity can lead to tremendous backlash against alternative narratives. But one can still ask how one gets from an isolationist attitude to one that is dangerous toward others. In other words, how do religious narratives turn villainous? Understanding the transformation of narrative will illuminate the religious villain.

As described above, religion is a kind of interpretive act, the process of understanding oneself in relation to the world and the holy as the grounding center of the world. One becomes oneself in the process of interpretation. And as Mark Juergensmeyer explains in his extensive study of violence and religion, those who are most likely to embrace a villainous religious narrative are those who find themselves marginalized, lost, and in need of a center that orders and may even silence the multiplicity of voices (Terror 152-158). The combination of lived experience and cultural attitudes make the conditions right for the construction of narratives that explain the whole and which villainize the other to such a degree that the narratives themselves become villainous (Terror 11). Whether individual or collectively driven, the villainizing of the other within a meta-narrative leads to villainous narratives that justify the acts of religious villains.

Meta-narratives are constructed to be liberated from context because they are understood as addressing the whole world, whether or not the world recognizes the authority of these narratives. The primary place one will find villainous narratives and religious villains is in extreme expressions of fundamentalism. In fundamentalism meta-narrative is the form of religious narrative. In their extensive study of fundamentalism worldwide, Martin Marty and Scott Appleby identified commonalities in fundamentalism that can lead to the villainizing of the religious narrative and promote religious villains. Fundamentalism is the claim that there are core values of a community that are non-negotiable, and to lose those is to 
lose everything. Therefore, as Marty and Appleby describe it, fundamentalists will defend the core values "with great innovative power" (ix). This innovation is a part of the construction of sacred history that can unfold as a villainous and villainizing narrative. Often one finds particular, charismatic leaders who drive these narratives, and then one sees the multitude of people who are drawn to it as a way to belong in and make sense of the world. ${ }^{4}$ The concern here is a particular kind of fundamentalism. As described by Juergensmeyer, Reza Aslan and others, religious justification for acts of violence arises within an understanding of oneself and one's community as living in a cosmic war with evil, usually in the form of secularism and religious complicity with secularism (Juergensmeyer "Religious Nationalism” 1-20).

Discussions of fundamentalism lead to the realization that any narrative with fundamental claims which are non-negotiable for membership will see any challenge to those claims as a threat to the core identity of the community (Marty and Appleby "Users Guide"), to lose those beliefs is to lose oneself. Faith, after all, is a centered act of the whole personality, as Tillich pointed out (Dynamics 4-9). Loss of the beliefs that express one's faith is loss of oneself. Such narratives do not lend themselves to contextualizing without much discussion. But not all such paths are dangerous. The beliefs give belonging and help the world make sense (Tillich Courage 86-103). Villainous narratives, on the other hand, are narratives that in their meta-perspective seek the destruction of all others. It is the height of hubris for a human mind to think it has all the answers to the desires of the divine mind. There are times when fanatical obsession with a narrative means devaluing the integrity of life in general of anyone living outside one's narrative. One must unrepentantly hold to such narratives and their consequences in order to be considered a villain. Not all who follow such narratives do so without remorse and without the ability to challenge the narratives.

When I am talking about villainous narratives, then, I am referring to narratives that are given ultimate status as the meta-narrative. To call a narrative destructive is to pass judgment, to claim that something was distorted somewhere and the story itself became a threat to the good, perhaps to life itself. The integrity of life demonstrates a concern with how human beings interact with the world for the good of the world, but in a world infused with the holy. Within a Christian application, one might look to how one lives "before God." Villainous narratives that thwart the good in any of these areas seem to be an affront to the common good and are both villainized and villainous. Take the following examples:

In February 1984, Rev. Michael Bray and a friend blew up a building claiming, "Before daybreak, the only abortion chamber in Dover was gutted by fire and put out of the business of butchering babies" (Juergensmeyer Terror 20). 
Connected to the Army of God movement, and supposed author of the manual Army of God, and publisher of Capitol Area Christian News, Rev. Bray's Defensive Action movement has justified the use of violence in anti-abortion activities on the basis of his understanding of Christianity. Bray sees the United States as being at odds with its own values, "undermining individual freedoms and moral values" by not allowing him to live under the biblical law he thinks should govern American society (Juergensmeyer Terror 23). As described by Juergensmeyer, Bray

was convinced that if there were some dramatic event, such as economic collapse or social chaos, the demonic role of the government would be revealed, and people would have "the strength and the zeal to take up arms" in a revolutionary struggle. What he envisioned as the outcome of that struggle was the establishment of a new moral order in America, one based on biblical law and a spiritual, rather than a secular, social compact. (Terror 23)

There are many similarities between Bray and Breivik. Bray's narrative is villainous in two ways. First, it is a villainizing narrative. Bray and his colleagues are at war with the evil that seeks to destroy the Biblical values of the United States. Second, it is a villainous narrative and Bray is a religious villain. It promotes the destruction of the goods of society in the name of the good as he sees it. He has shaped a narrative that puts him at the epicenter of knowing the way God wants people to live and any deviation from that is a threat that must be destroyed. In the process, he threatens basic, social, and intellectual goods by threating life, human relationships, and the capacity of those who follow him to see a wider worldview than the one he provides. There is no living in community by integrating the differences of life. There is only his way of seeing community.

In 1994, Rev. Paul Hill, a friend of Bray's, killed Dr. John Britton and his escort. Later, Hill wrote to Bray and others about what it was like to have killed these two men. Juergensmeyer describes Hill:

"My eyes were opened to the enormous impact" such an event would have, he wrote, adding that "the effect would be incalculable." Hill said that he opened his Bible and found sustenance in Psalm 91: "you will not be afraid of the terror by night, or of the arrow that flies by day." Hill interpreted this as an affirmation that his act was biblically approved.” (Ter- 
ror 23)

While by the definition set forth in this essay these narratives would seem villainous and the men religious villains, but that is not the whole picture. The complication of religious villains is that there is some sense of the integrity of life, if severally restricted. From the standpoint of the damage done and lives lost, there appears to be no integrity in these acts and they are judged as villainous. But recall my earlier claim about the construction of sacred histories. The world is being read in a particular way. There may be actual fictions at work (The Turner Diaries of Christian Identity or the Left Behind series), but these are all a part of the larger narrative. In the case of Bray and Hill, it is Christian Reconstruction that is at work, and Christian Reconstruction has a clear idea of how the world works, not just for them, but for everyone. The following passage comes at the end of a speech made in 2005 to a group of Reconstructionists by Rev. Mark Rushdoony, son of the founder of the movement. He said:

The power of Christian Reconstruction lies in the fact that it walks not by sight but by faith that Jesus Christ is now victorious and His victory over men and nations will be revealed in time and history.

My father's final exhortation to the family was

We have a certain victory. We are ordained to victory...

We have an ordination to victory in this battle...

Oh my God we thank thee for this great calling to victory.

Oh my God bless us in this battle!

(http://chalcedon.edu/research/articles/the-continuing-legacyof-christian-reconstruction/)

In the rhetoric that becomes action there is a plan, a vision of the whole. In carrying out destructive acts, these men are not doing so arbitrarily. They see themselves as fulfilling an obligation to realize the universal telos of the world as given in their villainizing meta-narrative. As Juergensmeyer explains, these men see themselves as saving the world by fighting evil. Villainous narratives begin in 
villainizing narratives, seeing the world as having become so corrupt that no amount of discussion will bring about the necessary change. The acts may seem small, but they leave a mark. The narratives of Reconstruction claim after a thousand years of Christian rule, Jesus will come again, but it is up to the people to prepare the world for Christ. The goal is a Christian theocratic state, and once that is achieved peace will reign and it will be possible to live a life of integrity (Juergensmeyer Terror 10).

Religion is dangerous when it threatens the integrity of life. Such narratives are simultaneously villainizing narratives - the way the world is being distorted and good is threatened by the forces of evil—and villainous narratives - that the only path to winning a cosmic war is perpetual fighting against enemies wherever they might be found. The villains of religion are those who show unwavering commitment to this war. Overcoming these villainizing and villainous narratives cannot, then, be framed in terms of conflict and conquering. An alternative approach to narrative construction is required.

Meta-narratives fail because even within the attempts to create such narratives they are developed in order to silence dissenting voices and the voices of otherness, the very voices that indicate a single narrative cannot account for all perspectives. If a single narrative of the whole were possible, within Christianity there would not have been multiple ecumenical councils nor would there continue to be the ever-growing diversity of Christianity today. What a meta-narrative fails to account for is alterity. The other is not me, nor can I turn the other into me. As described before, hermeneutics is not a simple reading of the data, but a reading of the data as it appears to me. What can be added to that definition is that hermeneutics is other oriented in that it is an attempt to understand myself in light of what is not me. John D. Caputo puts it in the following way:

Let us agree that hermeneutics is what Hans-Georg Gadamer says it is, and beautifully, too, viz., a way of putting one's own horizon or standpoint "into play" (ins Spiel) and thereby putting it "at risk" (aufs Spiel) (WM, 366; TM, 388). Then the difference between Gadamer's hermeneutical theory, to which I am deeply indebted, and deconstruction, to which I am still more indebted, turns specifically on the question of risk, of the high stakes game into which one enters, or into which one is entered, like it or not, by the approach of the other. (More Radical Hermeneutics 41)

Caputo will go on to say that any attempt to prepare for the other, to know 
what comes with the other, is to reflect myself and deny the alterity of the other. Recognition of alterity risks certainty. But in risking certainty integrity is gained.

The hermeneutical process cannot, in the end, create a single narrative, for such a narrative denies the reality of alterity. I cannot know the other. Moreover, as Caputo points out, I do not know myself. In the exchange with the other I shape my own identity through my perception, the narrative I have and how it unfolds through the complex layers of information that shape my interpretation of the other. In the end, the narrative I create is not a holistic narrative of self and other, a meta-narrative. Rather, what is created is a contextual narrative, the story of oneself or one's community in light of all the data presented in the encounter with the otherness of life. There is no meta-narrative. There are contextualnarratives that are open to transformation at every moment with each new piece of information, depending upon how it is received. What makes a meta-narrative meta is the interpreter, the one who sees it as the sole way of interpreting the world. What postmodernity has pointed out is the danger of such meta-narratives because of their inability to see past their own contextual frameworks.

\section{Contextual Narratives and Breaking the Bonds of Meta-Narrative}

As mentioned earlier, the counter point of the meta-narrative is the contextual narrative. Contextual narratives are context dependent, often self-consciously so. They may or may not project a telos, but they do express the identity and shape the engagement of individuals and communities in specific times and places when conscious of their contextuality. They are fluid, adapting to contextual changes, and they are limited in scope. They do not speak for the world, but rather to the world as the tool for an individual or community to make sense of the world. Talking about contextual narratives makes space for a multiplicity of views, and therefore recognizing one's own narrative as a contextual narrative also makes space in one's own interpretation of reality for that multiplicity. Given the condition of multiculturality of the present world, one cannot help but see the multiplicity of narratives (Steger 1-16). Each one gives both a sense of belonging to a particular community in such a way that life can be ordered and meaningful, and a sense of how one fits into a larger world. From that standpoint, there is no meta-narrative, no one story of the world and history that over-rules all others. This is good news and bad news. The good news is that there is an opportunity to see the engagement, blending, and transformation of these stories in an ever changing network. The bad news is this very multiplicity can leave people feeling threatened and can cause a crisis of belief - the fear that nothing gives meaning 
to life.

In his short text, The End of Story, Crispin Sartwell challenges such thinkers as McIntyre, Ricoeur, and others on the necessity of narrative. His concern is with the hegemony of narrative, the claim that life is only understood and given meaning through the activity of telling one's story. More specifically, he is concerned that life is turned into a project, given an artificial structure and telos. He claims that the activity of narration places an artificial structure that obscures the ability of people to be in the world and be present. I propose that the very act of challenging the dominance of narrative opens up possibilities in the reconfiguring of narrative through the reinterpretation of villainous narratives of religion.

Sartwell begins with a critique of the obsession with narrative, that one's life has a clear trajectory and telos by which the success or failure of a life can be measured. There are different ways of framing narrative, and for Sartwell, the story of faith told through Abraham by Kierkegaard breaks the bondage to narrative, at least in a simple, linear, rule-bearing and role-bearing form of narrative. In Abraham, the narrative of faith breaks apart the ethical narrative structure, making room for non-narrative elements within narrative itself (Sartwell 32). What Sartwell is trying to show is that in relinquishing his telos Abraham becomes himself. The narrative narrates the loss of narrative (Sartwell 36). But what Sartwell must also recognize is that what is happening is the loss of exclusivist narrative for the sake of that narrative. The exclusivist story is destructive.

The reason discussion of narrative cannot be abandoned is because narrative itself cannot be abandoned. One cannot counter destructive narratives by labeling them villainous and expecting proponents of them to accept that and embrace a life beyond story. Sartwell points not to the complete loss of narrative but rather to the transformation of narrative. The story is broken apart, and in breaking it apart, perspective is gained. There are two things at work, then. The first is the danger of a single-minded teleological narrative from which one cannot diverge. Such narratives lead to self and other destruction. But, as Juergensmeyer points out, the single-minded story only works if one does not ask too many questions.

The second thing Sartwell's reading of the Abraham moment does is regain the story as the story of a person who belongs, who has an identity. Abraham was and continues to be Isaac's father, but now his vision is expanded, his horizons are broadened. The story, though altered, does not cease to function as a part of Abraham's self-understanding. Through discourse, as Tillich might argue, the story can be challenged. The power of doubt within faith prevents faith from becoming a single-minded teleological trajectory of certainty (Tillich Dynamics 1825). There is an embracing of unintelligibility and incomprehensibility in Sartwell's work that can become a path beyond absolutizing narratives. 
Contextual narratives can be an opportunity for growth as a member of an integrated world, if one recognizes these narratives as contextual and is not threatened by that status. However, contextual narratives are not always recognized as such by those who hold them. Contextual narratives describe all religious narrative to a degree, because all are context dependent. Not recognizing this contextuality is what gives rise to the meta-narrative. A meta-narrative that is exclusivistic and even hostile toward the other is where the villainous narrative arises. While providing a sense of belonging and order to a world that seems chaotic and frightening, the villainous meta-narrative puts one in bondage to a narrative that is destructive of the integrity of life of the other. This happens because the narrative of the other is not given validity and is itself villainized as a part of one's own villainous narrative. In order to break these bonds one must find a way to gain a sense of the contextual nature of one's narratives.

The religious villain is one who, in the face of the evidence of contextuality and destruction of the integrity of life, refuses to see it. It is possible for there to be people who commit so profoundly to a villainous and villainizing narrative that any attempt to reach out and tap into the embedded notion of the integrity of life would be mocked and completely rejected. These are villains of religion, and by the definition set forth earlier in this essay, cannot be reached. The metanarrative is not value free, it is filled with a sense of the value and integrity of life of those within the narrative, but denies that to those outside of it. But their position need not be the final word on the impact of religion in the world. While their narratives continue, it is possible to transform some of the supporters of and participants in these narratives who are not villains.

The contextual narrative is the awakening of the value of both oneself and the other. A religious villain holds fast to the meta-narrative regardless of the outcome, and does so because the villain refuses to recognize his or her own contextuality. Others who have bought into the narrative, however, can potentially have their eyes opened, particularly if a cognitive dissonance is laid before them. Take, for example, a would-be Hamas suicide bomber described by Juergensmeyer. When asked if he could have taken the lives of Israeli bystanders he unequivocally said yes, proclaiming his hatred for the Jews. But it was also discovered that he was a tremendous soccer fan and had favorites on the Israeli national soccer team. When asked if he could have exploded the bomb during a soccer match he suddenly realized he could not (Juergensmeyer Terror 247). He experienced a cognitive dissonance between the narrative that villainized the Israelis and an underlying narrative of things that brought joy to his life and the value of others, including others he in some sense considered his enemies who deserved death. It is in breaking apart these narratives and reconstructing the narratives through the 
kernel of the integrity of life in them that transformation becomes possible.

\section{Trans-contextual Narrative and the Integrity of Life}

Much time has been spent defending mainstream, moderate, or "ordinary" followers of religious traditions against the stereotypes that arise because of fundamentalist or radical acts of violence in the name of religion. But one might ask what is accomplished by such distancing, isolating, and vilifying? Is it possible to identify villainous narratives before they begin promoting and justifying acts of violence both locally and internationally? Narrative drives communities, and charismatic leaders shape the nature of those communities. If the narratives are destructive of human flourishing, it is the leadership promoting the narrative that bears much of the responsibility for the acts. They are villains from the standpoint of human flourishing because their concern is not for the integrity of human life, but rather the flourishing of the narrative through its continued propagation and ultimate conquest of all others, by force if necessary.

It is not that there is no concern with the integrity of life, but rather, in claiming meta-narrative status, that integrity is recognized only for the insider of the narrative, not those who appear to threaten it. In fighting for the integrity of life the integrity of life is destroyed. While it may not be possible to convince the central authors of these narratives of the contextual and distorted nature of the narrative, highlighting the violation of the integrity of life in the right way may allow for those who follow it to think differently. Such narrative transformation must happen in a way that the internal integrity that is being protected by the original narrative is not itself lost, though the understanding of it may also face some transformation. If concern for the integrity of life can provide a trans-contextual narrative of human flourishing, then how we choose to engage these narratives matters, by beginning the conversation and awakening recognition of concern for the integrity of life that is also embedded in these narratives. That, after all, is what they seek when they seek peace as the outcome of violence (Juergensmeyer "Religious Nationalism" 17-18). In this initial recognition, it seems, the process of narrative transformation is begun.

In her first book, Tragic Vision and Divine Compassion: A Contemporary Theodicy, Wendy Farley seeks to challenge traditional theodicy that explains evil as a just punishment for sin or as educational. She claims such an understanding of the relationship of God to evil is utterly insufficient and even offensive for those who suffer radical evil. Radical suffering, for Farley, is evil that robs one of one's humanity - that the perpetrator of evil must see the victim as not human 
and in the suffering the person loses a sense of her own humanity. Her theodicy describes such evil through sin as a "rupture of creation" that includes deception, callousness, and bondage among other things (Farley 40-42). What Farley is claiming is that evil is embedded in the world and a part of an overall context where one can be desensitized "with an apathy that cannot be moved by another's sorrow" (Farley 46). Farley goes on to argue that to see evil in terms of tragedy rather than the fall of traditional theodicy allows one to re-evaluate the nature of the evil that causes radical suffering. She argues that callousness is brought about by a conditioning process that is subtle, long-term, and institutionalized in a society. One loses one's ability to see the suffering of another as one's problem and can even distance oneself enough to inflict this suffering with utter disregard. In the process one is in bondage to that evil (Farley 48). In the evaluation of religious villains, Farley appears to be identifying the conditions under which villainy arises, but she is not simply villainizing. She is pushing toward a way of thinking that allows for transformation for both the victims and the perpetrators of violence done within the framework of villainous and villainizing religious narratives by transforming the narrative.

Farley argues for a reading of evil within the context of divine compassion manifest in the compassion a person has for the other-both the other who suffers and the other who inflicts suffering. Farley's argument is that divine compassion resists evil by both empowering the victims of radical suffering to regain their humanity and empowering the perpetrators of violence to feel the compassion of another and in the process regain their own sense of compassion to reach out to the other (Farley 86-89). In reshaping their story this identity and relationship to each other is also transformed.

Farley's analysis of evil leads to a path of mediation. In recognizing the damaged context of life in the world, along with an awareness of the role the integrity of life plays in religious narratives generally, the possibility of combating villainous narratives arises. The concern is how to mediate between a multiplicity of perspectives while maintaining the sense of center and belonging provided by any particular narrative in order to promote human flourishing generally. If one could rethink meta-narratives, one could find the drive toward the integrity of life in them and find responses to the villains of religion and its dangerous paths. Promoting recognition of these narratives as contextual narratives is the first stage leading to a redemption of the narratives through a different hermeneutical approach-the trans-contextual narrative. A trans-contextual narrative of human flourishing blends contextual narratives without losing their uniqueness.

This hermeneutical process becomes not only an intellectual exercise, but in its ethical application becomes an act of redemption. Redemption is the process of 
overcoming lack or need. In this case, lack of both understanding and a sense of shared humanity perpetuates a hostile environment allowing a community's narratives to become both internally and externally villainous. The creation of a trans-contextual narrative of human flourishing, then, redeems contextual narratives, allowing them to speak for the communities from which they arise while at the same time broadening the perspective of those communities and the possibility for overcoming villainous and villainizing tendencies. Such change cannot reach everyone. Absolute commitment to a narrative is not lightly tossed aside. The villain of religion makes the process ongoing and ever incomplete. But there are those who have espoused villainous and villainizing narratives who are not themselves villains, as seen in the earlier example of the almost suicide bomber.

A trans-contextual narrative is not limited to a particular context while at the same time is aware of always having multiple, interacting contexts. ${ }^{5}$ A transcontextual narrative, in order to be successful, must be self-negating in the way Tillich describes religious symbols (Tillich Dynamics 47ff). Such a narrative must be able to sacrifice itself for the reality to which it points in order to build bridges between ever changing communities of narratives.

In an effort to make sense of a world pushed around by a multitude of contextual narratives, some contextual narratives have a crisis of identity and imagine themselves to be meta-narratives. If the drive to narrative is the drive to identity, to understand oneself as a being in the world, the cacophony of contextual narratives both gives and takes away that sense of belonging and identity. In the drive to understand ourselves by understanding the world, we seek a way to blend these narratives. But they cannot be simply blended into a single story. The contextual narratives have distinct qualities to them of genuine value for those who live in them. Reducing them all to one universal point of view does violence to them, and robs them of their ability to give meaning and belonging. A transcontextual narrative is one that is at the meeting point of contextual narratives, places where from their own points of view, they blend. Because, even though these contextual narratives reflect distinct points of view, they reflect distinct human points of view, and ways of understanding ourselves as human beings in the world. And thus, while the origin points and trajectories may be different, they are still asking the question of how to live a good human life. Theological humanism, then, can provide a framework or space to see these blends in contextual narratives and construct a trans-contextual narrative of human flourishing. This narrative is based on theological humanism's concern with the integrity of life in the relationship between humanity and the divine.

At the end of Juergensmeyer's analysis of religious terrorism, he proposes five possibilities of how to engage these destructive contextual narratives. While he 
finds the first four to be unsuccessful, the final solution points to the value of theological humanism as I have described it and the construction of transcontextual narratives of human flourishing. This option is to heal politics with religion rather than without. Belonging within a community is maintained by taking the concerns of the community seriously and in particular the goals of the community. These goals are various explanations of a peaceful world, one where people are allowed to define and seek all three types of goods. In finding the overlapping actual concerns with the integrity of life, then, it is possible to begin to seek mediating solutions. Being given respect, Juergensmeyer points out, can potentially lead to giving respect towards the other (Juergensmeyer Terror 247).

While the integrity of life can be used as a standard for identifying both religious villains and villainous religious narratives, it also serves as the path beyond religious villainy. The drive toward wholeness found in religion of any kind is a drive toward the integrity of life. Recognizing that drive in oneself and another allows one to see the other as a person with value, dignity, and integrity. But in order to see this, the cognitive dissonance between villainous components of religious narratives and the underlying concern with the integrity of life need to be made explicit. In the transformation of the narrative its contextual quality is revealed and its capacity for connection with others espousing the same transcontextual notion of the integrity of life becomes a bridge between competing narratives. What is required, then, is the willingness to be very cautious in the application of the idea of villain. Labeled a villain, there is not motivation for change. Moreover, when one is made the villain of someone else's story that person in turn villainizes the one who has villainized him or her. The cycle can be brought to an end by rethinking one's own narrative and its limitations as the foundation of individual and community identity, as well as the understanding of the "other" as a character in one's story.

What this essay seeks to promote is an engagement of religious narratives. One concern raised by Caputo is the infinite gap between self-and other. It is this gap that eliminates the possibility of a meta-narrative. But a world where everyone simply lives in contextual narratives is not a world that can function well within the larger context of the global integrity of life. What I propose is a transcontextual narrative. There is always a risk of the trans-contextual narrative becoming its own meta-narrative, but rather than a distinct view of the world transcontextual narrative employs Ricouer's hermeneutical notion of dialogue. The trans-contextual narrative is the ever-unfolding dialogue between contextual narratives through which we become ourselves as relational and integrated, that is, connected and respectful, members of global civil society rather than seeking to dominate each other through constant villainization and villainous acts. It is an 
attempt at building cooperation across narrative lines that shape our very identities.

\section{Notes}

${ }^{1}$ See Robert Baird's Category Formation, Sallie McFague’s "God's Household” in Subverting Greed, B.H. McLean's Biblical Interpretation and Philosophical Hermeneutics, Philip Davies Memories of Ancient Israel. among others.

${ }^{2}$ See the following:

http://topics.nytimes.com/top/reference/timestopics/people/b/anders_behring_bre ivik/index.html www.bbc.co.uk/news/world-europe-17766404 www.guardian.co.uk/world/2012/apr18/anders-behring-breivik-serb-nationalist www.guardian.co.uk/world/anders-behring-brevik www.huffingtonpost.com/gail-a-hornstein/the-case-of-norwaysander_b_1540210.html

${ }^{3}$ While "contextual narrative" is my own term, discussions of little narratives and the like address the same phenomenon. See the writings of Jean-Francois Lyotard, Mark C. Taylor, and Kevin J. Vanhoozer.

${ }^{4}$ See, for example, Pat Robertson, James Dobson, Charles L. Worley, and Fred Phelps.

${ }^{5}$ Robert von Thaden Jr. first coined this term in 2010.

\section{Works Cited}

Aslan, Reza. No god but God: The Origins, Evolution, and Future of Islam. New York: Random House, 2006, Print.

Aslan, Reza. How to Win a Cosmic War: God, Globalization, and the End of the War on Terror. New York: Random House, 2009, Print.

Augustine. Confessions. Translated by Maria Boulding, O.S.B. New York: Vintage Books, 1997, Print.

Baird, Robert. Category Formation and the History of Religions. Berlin: deGruyter, 1991, Print.

BBC. www.bbc.co.uk/news/world-europe-17766404. May 23, 2012, Web.

Caputo, John D. More Radical Hermeneutics: On Not Knowing Who We Are. Bloomington: Indiana University Press, 2000, Print.

Clingerman, Forrest. "Interpreting Heaven and Earth: The Theological Construction of Nature, Place, and the Built Environment." In Nature, Space and the Sacred. Edited by Sigurd Bergmann, Peter

Scott, Heinrich Bedford Strohm and Maria Jansdotter, Ashgate Publishing, 2009, Print. 
Davies, Philip R. Memories of Ancient Israel: An Introduction to Biblical History - Ancient and Modern. Louiseville: Westminster John Knox, 2008, Print.

Eliade, Mircea. The Sacred and The Profane: The Nature of Religion. Orlando: Harcort, Inc., 1959, Print.

Farley, Wendy. Tragic Vision and Divine Compassion: A Contemporary Theodicy. Louisville: Westminster/John Knox Press, 1990, Print.

Gadamer, Hans Georg. Truth and Method. New York: Continuum International Publishing Group, 1989, Print.

The Guardian. www.guardian.co.uk/world/2012/apr18/anders-behring-breivikserb-nationalist. May 23, 2013, Web.

The Guardian. www.guardian.co.uk/world/anders-behring-brevik. May, 23, 2012, Web.

The Huffington Post. www.huffingtonpost.com/gail-a-hornstein/the-case-ofnorways-ander_b_1540210.html. May 23, 2012, Web.

Juergensmeyer, Mark. Terror in the Mind of God: The global Rise of Religious Violence Third Edition. Berkeley: University of California Press, 2003, Print.

Juergensmeyer, Mark. "The Worldwide Rise of Religious Nationalism” in Journal of International Affairs. New York: Columbia University, Summer 1996, 50:1, Print.

Klemm, David and Schweiker, William. Religion and the Human Future: An Essay on Theological Humanism. Wiley-Blackwell, 2008, Print.

Marty, Martin and Appleby, Scott (eds), 'The Fundamentalism Project: A User's Guide' in The Fundamentalism Project: Fundamentalisms Observed. Chicago: University of Chicago Press, 1991, Print.

McFague, Sallie. "God's Household: Christianity, Economics, and Planetary Living” in Subverting Greed: Religious Perspectives on the Global Economy. Knitter and Muzaffor, eds. New York: Orbis Books, 2002, Print.

McLean, B. H. Biblical Interpretation and Philosophical Hermeneutics. Cambridge: Cambridge University Press, 2012, Print.

New York Times. http://topics.nytimes.com/top/reference/timestopics/people/b/ anders_behring_breivik/index.html. May 23, 2012, Web.

Plato. Republic. Translated by G.M.A. Grube. Indiana: Hackett Publishing, 1992, Print.

Ricoeur, Paul. “What Is a Text?” in From Text to Action: Essays in Hermeneutics, II. Evanston: Northwestern University Press, 1991, Print.

Ricoeur, Paul. Oneself as Another translated by Kathleen Blamey, Chicago: University of Chicago Press, 1992, Print.

Ricoeur, Paul. "Toward a Narrative Theology: Its Necessity, Its Resources, Its Difficulties," in Figuring the Sacred: Religion, Narrative, and Imagination. Minneapolis: Fortress Press, 1995, Print. 
Rushdoony, Mark. "The Power of Christian Reconstruction." http://chalcedon.edu/research/articles/the-continuing-legacy-of-christianreconstruction/ May 26, 2012, Web.

Sartwell, Crispin. End of Story: Toward and Annihilation of Language and History. New York, State University of New York Press, 2000, Print.

Steger, Manfred B. Globalization: A Very Short Introduction. Oxford: Oxford University Press, 2009, Print.

Taylor, Mark C. Erring: A Postmodern A/theology. Chicago: University of Chicago Press, 1984, Print.

Tillich, Paul. The Courage to Be. New Haven: Yale University Press, 1952, Print. Tillich, Paul. Systematic Theology, 3 vols. Chicago: University of Chicago Press, 1957, Print.

Tillich, Paul. What Is Religion. Translated by James Luther Adams. New York: Harper and Row, 1969, Print.

Tillich, Paul. The Dynamics of Faith. New York: Perennial Classics, 2001, Print.

Todorov, Tzvetan Imperfect Garden. Princeton: Princeton University Press, 2002, Print. 